\title{
WORK-LIFE BALANCE: A PERSPECTIVE OF MULTINATIONAL CORPORATION (MNCs) EMPLOYEE
}

\author{
N. Yolan Pradita \\ Universitas Kristen Satya Wacana \\ yolan.pradita@gmail.com \\ Rosaly Franksiska \\ Universitas Kristen Satya Wacana \\ rosaly_fran@yahoo.com
}

\section{Suggested Citation:}

Fisher, Gwenith G., Carrie A. Bulger, and Carlla S. Smith. 2009. "Beyond Work and Family: A Measure of Work/Nonwork Interference and Enhancement." Journal of Occupational Health Psychology 14(4):441-56.

\section{Abstract:}

For a company knowing the work life balance of their employee is a proper way to control the employee performance for company's development. This study on Work-life balance (WLB) is aimed to help both company and employees manage their family responsibilities, create flexible-work conditions and enable them to perform better particularly in Multinational Company (MNC). This research put forward on the four dimensions of Work life balance from the employee perspective in MNC. The four dimensions include Work Interference with Personal Life (WIPL), Personal Life Interference with Work (PLIW), Personal Life Enhancement of Work (PLEW) and Work Enhancement of Personal Life (WEPL). Deep analyzing on the employee characteristic using a descriptive quantitavive method is also conducted to the measurement of the work life balance to 100 employees in PT. NK. The interesting finding is found during the study whereby in PT. NK as a MNC most of the employees are in a moderate range of WLB and been measure by the cross tabulation with the employee characteristic. The other finding indicated that work life balance is an important aspect which supposed to be notice by a company for all of the employee particularly in a multinational company.

Keywords: Human Resource, MNC, Work Life Balance, Work-Personal Life

JEL Classification: M50 
Introduction

The role of human resources for a company is very essential not only as an asset for the company but it also has an impact on operationalization and the achievement of company's goal. The professionalism and the good performance of the human resource in the company can determine the company's advancement. The latest data from statistics Indonesia (2020) in February 2019 the total number of unemployment in Indonesia is 6.816 .840 peoples with the amount of people with the highest education completed in University is 839.019 peoples (bps.go.id). This total amount of unemployment represents the total amount of job seekers in Indonesia which means that there are many peoples in Indonesia are still looking for place to work. One reason people choose not to work is because they prioritize their work-life balance in their working place.

It was revealed by Unilever that the multinational corporation (MNC) based in Indonesia offer plenty of benefits to the employee such as health services-which include gym facilities, sport clubs, nursery room, daycare center, social activities, and spiritual activities (Unilever, 2019). Nevertheless, a survey result taken from a job provider site-jobstreet.com in 2016 indicated that local companies were more desirable rather than multinational companies. There were only three MNC which were included in ten desirable companies for job seekers in Indonesia. This survey involved 43.287 respondents in seven countries such as Indonesia, Malaysia, Singapore, Hong Kong, Philippines, Thailand, and Vietnam. The respondents were asked to choose ten companies that they wanted to work for. The result of the survey indicated that in four countries, local companies became the most interesting companies for those job seekers and Indonesia was included in those four countries. Only in Hong Kong, Singapore and Vietnam MNCs became the most desirable companies for the job seekers. In Indonesia, consumer goods industry became the first choice for most of the respondents of the survey. This survey revealed that work-life balance becomes one of the most important factor which affects people's mind to choose their working place. Someone's perception about the working place which they are dreaming of is determined by some factors such as quality of life. These factors hold important roles in building such perception. The factors which influence someone in choosing a working place are included in employee work-life balance.

The term "work-life balance" has closest meaning with the conflict of work-family. However, those words are still focused only on the scope of work and family. Work-life balance can simply be defined as a situation in which there is a balance between work time and employees' life convenience as the employees can still manage their life while working in a company (Kanthisree et al., 2013). Work-Life Balance is being aware of different demands on time and energy saving, the ability to make choices in the allocation of time and energy knowing what values to apply. Frame and Hartog (2003) interpreted a good work-life balance as the employees feeling in a condition when they are not limited to use their working hours flexibly to make it balance between their work and other concerns such as family, hobbies, art, travelling, studies and so forth, instead of focusing strictly on work. Oluwasola (2001) stated that work-life balance (WLB) concerns with the ability of the employees to prioritize between individual's lifestyle, health, social life, family and work. Work sometimes is considered as a part of individual's life. Work-life balance become an important issue both for the employees and the companies. It becomes important because when the employees are faced with one or more work demands to be accomplished that is very tiring, when the employees are not able to fulfill the demands, it may cause stress for the employees and reduce their productivity.

Moreover, Nafiudin (2015) stated that someone will also tend to choose another job or stop to work to balance both the work and personal life. Ideally, when the company wants to implement work-life balance, the company will provide some supports to the workers. It was stated by Robbins and Judge (2011) that the work-life balance program includes resources on parent and child care, employee care, health and welfare of workers, relocation and others. Work-life imbalance can cause negative impacts both for the organization and the individuals (Crooker, Smith and Tabak, 2002). For organizations, work-life imbalance can lead to ineffective behavior in the workplace, such as absenteeism, which in turn will reduce performance. In addition, it can reduce the level of satisfaction and commitment to the organization, as well as increase turnover intention (Konrad and Mangel, 2000) As for individuals, the imbalance between work and family life will affect careers, mental health, stress levels, and 
life satisfaction (Crooker, Smith and Tabak, 2002). This is the one of the reasons why work-life balance becomes an important highlight in MNC, because understanding how the effectiveness of an individual in managing his personal life and work life will create benefits for individuals such as life satisfaction, healthy mentality, and good behavior. Whereas for organizations, it will provide benefits, namely job satisfaction which can lead to effective behavior in the workplace, which can greatly improve performance (Greenhaus, Collins and Shaw, 2003). Based on the background above this research is expected to answer the research question "How was the work life balance of MNCs' Employee in PT. NK?"

The purpose of this research is to test whether work-life balance at MNCs has been well managed by the company. This research is also expected to provide some benefits to develop the management of human resources in MNC, especially regarding work-life balance of the employee, so that the employee can feel comfortable in doing work without any hindrance because of their personal life. In addition, another benefit is that the result of this research can be a reference in the next research.

\section{Literature Review}

\section{Work-life Balance}

Fisher, Bulger, and Smith (2009) explained that when the work of an employee is intervening or interfering with personal life, it will interfere the work-life balance of the workers. Fisher also defined work-life balance as an effort that done by individuals to balance two or more roles which. Bailyn, Robert, and Kochan (2001) defined work -life balance as a harmonious and holistic integration of work and non-work, so that men and women can achieve their potential across the domains in which they play out their life roles. According to Schermerhorn, Hunt, and Osborn (2001) work-life balance is someone's ability to balance the demands of work with the personal needs and his family. Based on the definitions above, it can be concluded that work-life balance is the ability of someone to keep a balance between work and personal life-which includes family, so that it can minimize conflicts appearing from someone's life without any hindrance like other work or other life role later on.

Fisher (2001) stated that work-life balance is the work stressors which cover four essential components, they are time, strain, energy, and behavior. Time is about how much time that is used to work compared to the time that is spent to do activities outside the work. Strain in this context includes anxiety, pressure, loss of important personal activities, and difficulty to maintain attention. Energy is used to achieve someone's expected goals. Energy is a limited source in humans so that when there is a lack of energy to do work and activities outside work, it will increase stress. Behavior, is about the existence of an action to achieve someone's desired goal. This component is based on someone's belief that he is able to achieve what is desired in his work and personal goals.

Fisher et al. (2009) also put forward the dimensions of work-life balance. These dimensions are obtained from the development of measuring instruments based on four work-life balance components. The following are the four dimensions of work-life balance: Work Interference with Personal Life (WIPL), Personal Life Interference with Work (PLIW), Personal Life Enhancement of Work (PLEW), and Work Enhancement of Personal Life (WEPL). Work interference with personal life refers to how far work can interfere with the employees' personal life. For example, work can make it difficult for someone to manage time for his personal life, workers who must do their unfulfilled daily target in overtime. Thus, it can make workers spend more time for working rather than for their personal life. Personal Life Interference with Work refers to how far employees' personal life interferes with his work life. For instance, when individuals have problems in the personal life, this can interfere with the employees' performance at work. Employees who have unresolved personal problems with their family can make them less excited when they work and it will affect them in doing their work to meeting their target.

Personal Life Enhancement of Work refers to how far employees' personal life can improve the performance of individuals in work. For example, when individuals feel happy because of their life, their personality is filled with fun. So this can make their mood at work becomes fun. When workers are in a good mood due to 
personal life (family), then they will be more enthusiastic in doing their jobs. Work Enhancement of Personal Life refers to how far work can improve the quality of the individual's personal life. Skills that are acquired by individuals at work, allows individuals to use their skills in everyday life. For instance, training in sewing and pattern making that is obtained by workers from the company, can be used for employees' personal life.

\section{Prior Research}

Many approach are applied in various studies that had been conducted about work-life balance considering its importance in a company particularly in MNCs. One of the studies that has been done by Afroze (2019) revealed that work-life balance approach is still very new to Bangladesh and employees of different ages, gender, marital status and hierarchical positions in the two foreign companies experienced a difficult work-life balance. The finding has shown that the foreign organizations do have some of the work-life balance policies in place, but these facilities are not common among all the foreign companies. Not all employees equally use these workplace facilities, therefore employees still experienced a poor work-life balance. This research has demonstrated that there are more factors, which hinder than the ones that enable organizations' ability to effectively implement work-life balance practices. The study by Ouppara and Sy (2012) to the management Coca-cola Amatil of Sydney revealed that it is necessary that the company will undertake periodic reviews of the provisions of worklife balance in the work environment to ensure that those areas which need to be intensified leading to the existence of a totally motivated and committed workforce can be sustained, therefore a firm can ensure the existence of a highly motivated and efficient workforce thereby creating a more humane work environment in the firm.

Work environment is not only about the living world. It is necessary to ensure the quality and the balance of work life for all-round peace and prosperity. Better quality of work life leads to increased employee morale. It minimizes attrition and checks labor turnover and absenteeism. There will be better communication and understanding among all employees leading to cordial relations. It enhances the brand image for the company as that, in turn, encourages entry of new talent into the organizations work environment means the milieus around a person. It is the social and professional environment in which employees are supposed to interact with a number of people. Employees' are supposed to co-ordinate with each other in one way or the other. They may be working in a team or in dependent. It depends upon their position and status in their work place. It is not important that an office would always be called the work place. It can either be home environment where they use to work for all the time where they were supposed to interact with your family members by and by (Singh, 2017). It is stated by Leovaridis and Vătămănescu (2015) the employees work in their spare time, after hours (at evenings or in the week-end) in order to finish their tasks, which affects their personal lives. The employees also is offered by the situation when an important project has a short deadline, so that they might be asked to postpone their holidays. The study found that unbalance work-life could be seen by the usage of spare time to do work after working hours, and flexible time that is given to the employee can reduce the unbalance of work-life.

Jaharuddin and Zainol (2019) on their study found that a proper balance between work and life demands is an antecedent for employee engagement, because factors of employers, such as caring about employees, placing employees' interests first and flexibility are predictors of employee engagement. Therefore, balancing one role will benefit the other role. Companies with engaged employees have higher productivity, profitability, growth, customer satisfaction and employee retention due to reduced turnover and less intention to leave the company. On the other hand, companies with disengaged employees suffer from wasted efforts and bleed talent; they earn less commitment from employees, face increased absenteeism, have lower customer orientation, see less productivity, have reduced operating margins and earn lower net profit margins. Engagement enables workers to be good leaders that carry on their work with responsibility. Flexible forms of work bring many improvements, they meet the needs of employers and also the needs of employees who can better align their professional lives to the care of family (Sukalova, Ceniga and Janotova, 2015).

Improvements in people management practices, especially work time and work location flexibility, and the development of supportive managers, contribute to increased work-life balance. Work-life balance programs have 
been demonstrated to have an impact on employees in terms of recruitment, retention/turnover, commitment and satisfaction, absenteeism, productivity and accident rates. Companies that have implemented work-life balance programs recognize that employee welfare affects the -bottom linell of the business. Parameters are required to ensure that programs are having the desired effect on both employees and the company (Meenakshi and V, 2013). a successful convergence between work and non-work aspects can be a win-win situation for employees and employers alike. The ability to achieve satisfying experiences in all life domains enhances the quality of personal relationships and a range of organizational outcomes (Lazăr, Osoian and Raţiu, 2010).

\section{Research Methodology}

The type of this research is quantitative descriptive, that has a focus on having a clear description the analysis of work-life balance in MNCs. PT. NK is chosen as the research population in this study due to their ability to represent MNCs since the research is focusing on the work-life balance in an MNCs. The research samples are 100 employees in PT. NK, the total amount of samples from each population is 100 because the number exceeds ten percent of the total population (Sutopo, 2002). Purposive sampling method is chosen to be sampling method for this research because the samples is chosen based on any characteristics that fulfill the research samples' criteria. The data for this research are gathered using questionnaires which are distributed to the employees in both PT. NK. This research aims to examine the work-life balance at MNC, through these four dimensions: Work Interference with Personal Life (WIPL), Personal Life Interference with Work (PLIW), Personal Life Enhancement of Work (PLEW), and Work Enhancement of Personal Life (WEPL).

The data analysis technique used in this research is descriptive analytics with measures of center include the mean, median, and mode, while measures of variability include the standard deviation, variance, the minimum and maximum variables, and the kurtosis and skewness. By using descriptive statistics, the data which have been obtained through a questionnaire can determine the measurement of the concentration of data, the measurement of data distribution, and the presentation of data in the form of pie chart bar charts, and boxplot. Cross tabulation analysis is an analysis in the form of table method, which displays a cross tabulation or contingency table that is used to identify and find out whether there is a correlation or relationship between one variable with another variable.

Result

In this part explained about the characteristics of respondents as many as 100 peoples who are the officer in PT.NK consisting of respondent's length of employment, academic background, gender, age, income; spending; and saving per month which is served in table 2 . Table 2 shows that from 100 respondents are dominated by male officer by 53 percent. The age is the most dominated by the range between 25 and 30 years old with a percentage of 63 percent. While the least age is in the range of between 17 and 24 years old, by 4 percent. The respondent characteristics table also shows that, the background academic that was taken the most is a bachelor, with a percentage of 66 percent. While the number of background academic was taken least is Magister, which is 4 percent. Then, the longest employment is from 1 until 5 years with a percentage of 50 percent. Meanwhile the least is 10 until 15 years with a percentage of 2 percent. 
Table 1. Respondent Characteristics

\begin{tabular}{|c|c|c|c|}
\hline \multicolumn{2}{|c|}{ Respondent Characteristics } & Frequency & Percentage (\%) \\
\hline \multirow{3}{*}{ Gender } & Male & 57 & 57 \\
\hline & Female & 43 & 43 \\
\hline & Total & 100 & 100 \\
\hline \multirow{4}{*}{ Age } & 17-24 Years Old & 4 & 4 \\
\hline & 25-30 Years Old & 63 & 63 \\
\hline & $>31$ Years Old & 33 & 33 \\
\hline & Total & 100 & 100 \\
\hline \multirow{6}{*}{$\begin{array}{l}\text { Length of } \\
\text { Employment }\end{array}$} & $<1$ Years & 8 & 8 \\
\hline & $1-5$ Years & 50 & 50 \\
\hline & $5-10$ Years & 34 & 34 \\
\hline & $10-15$ Years & 2 & 2 \\
\hline & $>15$ Years & 6 & 6 \\
\hline & Total & 100 & 100 \\
\hline \multirow{4}{*}{$\begin{array}{c}\text { Academic } \\
\text { Background }\end{array}$} & Diploma & 30 & 30 \\
\hline & Bachelor (S1) & 66 & 66 \\
\hline & Magister (S2) & 4 & 4 \\
\hline & Total & 100 & 100 \\
\hline \multirow{4}{*}{ Monthly Income } & Rp. 2.000 .000 - Rp. 3.500 .000 & 31 & 31 \\
\hline & Rp. 3.500 .000 - Rp. 5.000 .000 & 59 & 59 \\
\hline & $>$ Rp. 5.000 .000 & 10 & 10 \\
\hline & Total & 100 & 100 \\
\hline \multirow{5}{*}{ Monthly Expenses } & $<\operatorname{Rp} 1.000 .000$ & 9 & 9 \\
\hline & Rp. 1.000 .000 - Rp. 2.500 .000 & 47 & 47 \\
\hline & Rp. 2.500 .000 - Rp. 4.000 .000 & 33 & 33 \\
\hline & > Rp. 4.000 .000 & 11 & 11 \\
\hline & Total & 100 & 100 \\
\hline \multirow{5}{*}{ Monthly Saving } & $<$ Rp. 500.000 & 42 & 42 \\
\hline & Rp. 500.000 - Rp. 1.500 .000 & 48 & 48 \\
\hline & Rp. 1.500 .000 - Rp. 3.000 .000 & 9 & 9 \\
\hline & > Rp. 3.000 .000 & 1 & 1 \\
\hline & Total & 100 & 100 \\
\hline
\end{tabular}

In table 1, with the total respondent of 100 in PT. NK most of the respondents gained monthly income between Rp. 3.500.000 and Rp. 5.000.000 with the percentage of 59 percent and the least is more than Rp. 5.000 .000 with the percentage of 10 percent. On the other side, most of the respondents have monthly expenses between Rp. 1.000 .000 and Rp. 2.500 .000 with the percentage of 47 percent of the respondent, and the least spent less than Rp. 1.000 .000 with the percentage of 9 percent. Furthermore, the respondent mostly saves the money between Rp. 500.000 and Rp. 1.500 .000 with the percentage of 48 percent and the least save the money more than Rp. 3.000 .000 with the percentage of 1 percent.

\section{Descriptive Data: The Dimensions of Work-Life Balance}

To show the Likert scale range of average questionnaire responses with all four dimensions of variable work-life balance in this study, it can be obtained with formula of maximum value minus minimum value divided by its maximum value, amounted to 0,8 . 
Table 2. Range of Variable Category

\begin{tabular}{|c|c|}
\hline Range & Category \\
\hline $4,20-5,00$ & Very High \\
\hline $3,40-4,19$ & High \\
\hline $2,60-3,39$ & Moderate \\
\hline $1,80-2,59$ & Low \\
\hline $1,00-1,79$ & Very Low \\
\hline
\end{tabular}

Source: Primary Data, 2019

Based on the results of descriptive analysis on variable work-life balance shown in table 3 , mean of the data is obtained 2.71 and standard deviation is 0.285 . This study is conducted in PT. NK which is a multinational company that expert in profesional kitchen equipment manufacture. Therefore the work-life balance in PT. NK is in the moderate category.

Table 3. Descriptive Statistic WLB Scale

\begin{tabular}{lcccccc}
\hline & N & Mean & $\begin{array}{c}\text { Std. } \\
\text { Deviation }\end{array}$ & Minimum & Maximum & Category \\
\hline Work-Life Balance & 100 & 2.61 & 1,06 & 1 & 5 & Moderate \\
\hline
\end{tabular}

Source: Primary Data, 2019

The average value of Work Interference with Personal Life (WIPL) of 2,34 is included in the low category. Highest average value is the statement " I come home from work too tired to do things I would like to do.", with an average value of 2,63. Meanwhile, the lowest average value is found in the statement " My personal life suffers because of my work.", with an average value of 1,85. Furthermore, the average value of Work Enhancement of Personal Life (WEPL) dimension of 2,56 which is included in the low category. The highest average value is found in the statement The skills developed at work make it easier for me to do things outside of work.", with an average value of 2,84. Meanwhile, value of the lowest average is stated in the statement " My job gives me energy to pursue activities outside of work that are important to me.", with an average value of 2,08.

It is indicated that the average value of Personal Life Interference with Work (PLIW) dimension is 3,67 which is included in the high category. The lowest average value is found in the statement " I am in a better mood at work because of everything I have going for me in my personal life." with a value of 3,22. Meanwhile, the value of the highest average is found in the statement "Support from my family makes me more enthusiastic in doing my work." with a value of 3.91. Meanwhile, the average value of Personal Life Enhancement of Work (PLEW) dimension of 2,27 is included in the low category. The highest average value is found in the statement "Personal and family needs require me to do work.", with an average value of 3,06 . Meanwhile, the lowest average value is stated in the statement " My work suffered because of everything that happened in my personal life.", with an average value of 1,89 .

\section{Analysis}

It is shown in figure 1, most of the officer in PT. NK have to go through a long distance to reach the company. Most of the officer have to pass about $9 \mathrm{KM}$ until $11 \mathrm{KM}$ to reach the company with the percentage of respondent 32 percent. Since the location of the company is in the industrial area, only few of people who have the nearest distance from home to the company about $3 \mathrm{KM}$ until $5 \mathrm{KM}$ with the percentage of 3 percent. Meanwhile, in figure 2 , most of the employee use motorcycle to go to the company because many of them only have 1 motorcycle in the family with the percentage of 33 percent. Those long distance that to be pass through made the employee have to go early to reach the company before the work time. 
Figure 1: Distance between Home and Work place

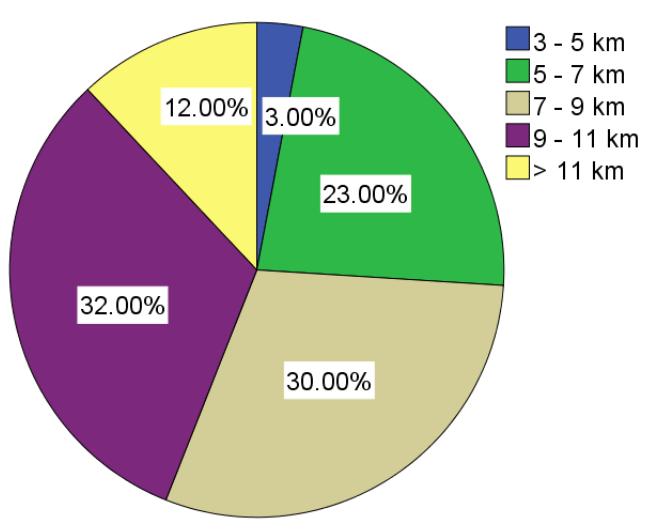

Source: Primary Data, 2019
Figure 2: Privately Owned Vehicle per Family

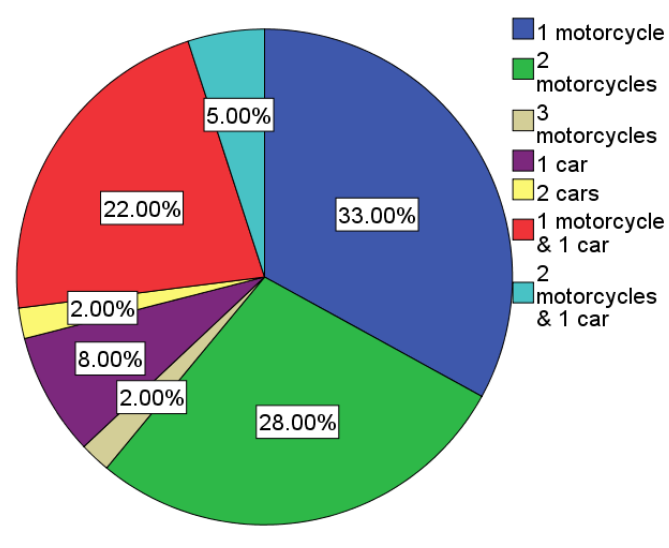

Source: Primary Data, 2019

It is shown in figure 3 that most of the employee still cannot fulfill the family need. 54 percent of the percentage feel that the income which is gained from the company have not been enough to fulfill the family needs. Rest of them feel enough to fulfill their need by the income. The employee in PT. NK still have to take a responsible for their family. It can be seen in figure 4, most of the employee still have a responsible for their parent, it takes 33 percent of the percentage. Beside that, the least number of percentage for the responsible is for the employee's wife or husband with the percentage of 2 percent, because most their family member particularly their couple have their own work.

Figure 3: Wheter the Income has fulfilled family needs

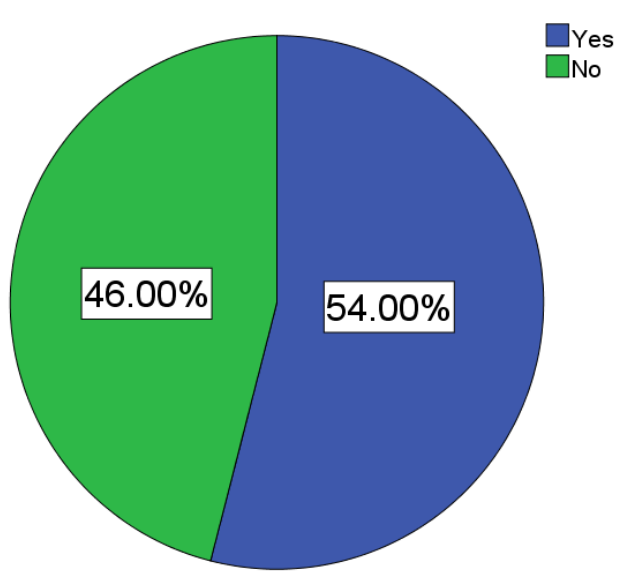

Source: Primary Data, 2019
Figure 4: Number of Family Dependants

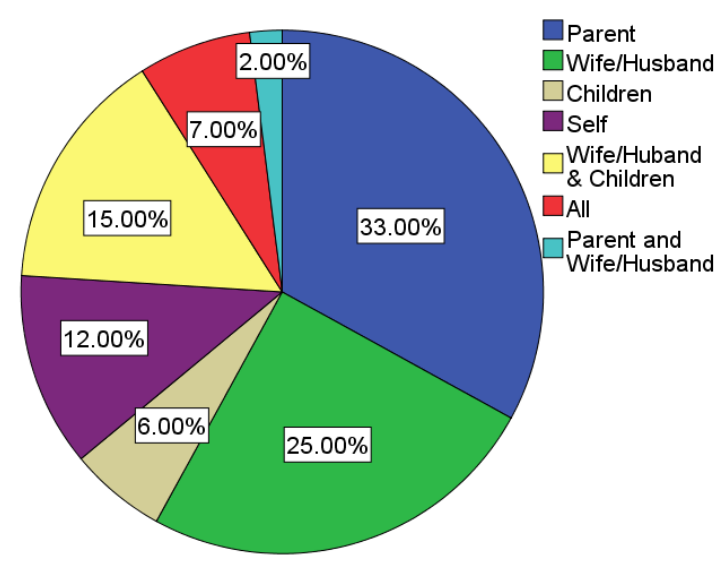

Source: Primary Data, 2019

Figure 5 shows that almost of the employee's family member all is having work. 62 percent of the percentage tells that in each family at least there are 2 persons who works. Furthermore, the 5 percent of the employee family there are 3 persons who having work. In diagram 6 , it shows that the reason of not only one person working in the family is various. 55,22 percent of the reason is because they have less income while the need and spending is more than the income that is gained from the company. the other reason is because 32,84 percent of the employee and their family have been working for a long time and still working until now. 
Figure 5: How Many Family Member is Working

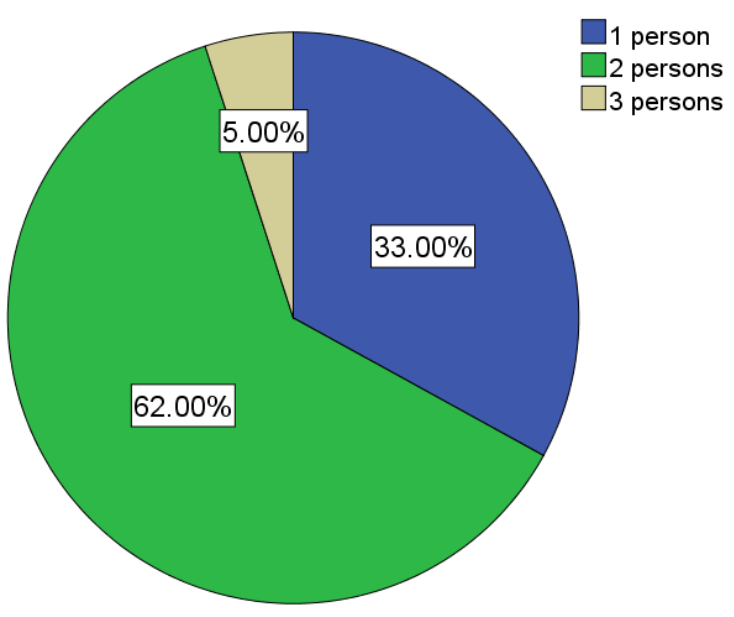

Source: Primary Data, 2019
Figure 6: Reasons why more than 1 person working in a family

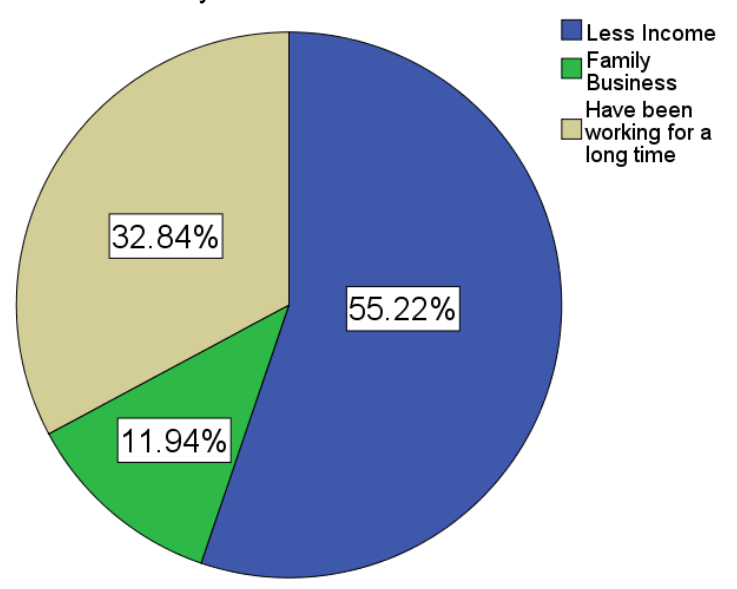

Source: Primary Data, 2019

It can be seen in figure 7 that 87 percent of the percentage do not have a housekeeper and the rest 13 percent of the percentage have a housekeeper at home. The reason of having and do not have a housekeeper is also various. Figure 8 shows that 46,15 percent of the employee have a housekeeper because they have a lot of house work to be done. They can not do the house work alone and need other person to do the work at home. 38,46 percent feel too busy to do the work and do not have enough time for it, while 15,38 percent of the employee looking for a housekeeper to do a childcare because they have no one to taking care their children. In Figure 9 it can be seen that some of the employee prefer to do not have a housekeeper because of any reason. 39,08 percent feel that by doing the house work themselves they can save their money for other needs. 33,33 percent feel that they do not need a housekeeper because they can do the house work by themselves. And the rest of the percentage, 27,59 percent still living in the boarding house so that they do not need a housekeeper.

Figure 7: Whether have a housekeeper

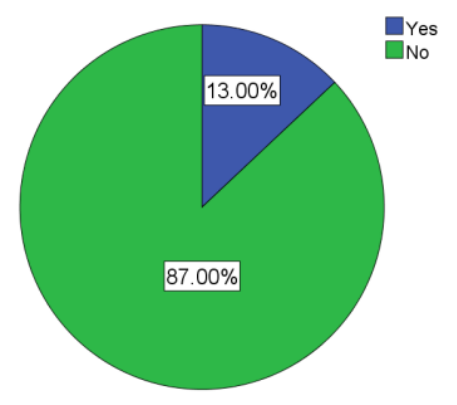

Source: Primary Data, 2019
Figure 8: The Reason for having a housekeeper

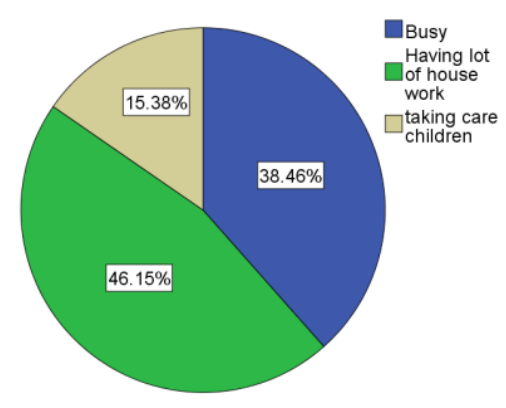

Source: Primary Data, 2019 
Figure 9: Reasons for not having a housekeeper

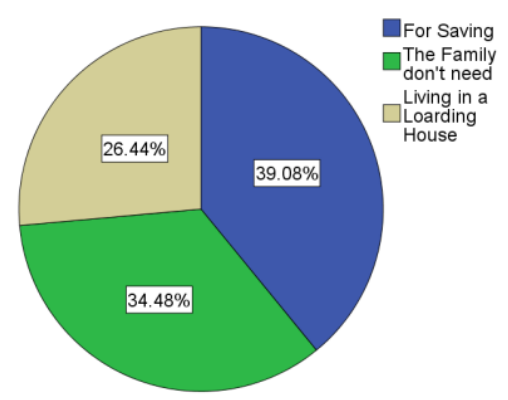

Source: Primary Data, 2019

Because of the obligation which is given by the company that the employee only can have a leave per month maximum 3 times, in the figure 10, 90 percent of the respondent per month take a leave between 1 and 3 times a month, most of the officer take the leave because of something deal with family with the percentage of 56 percent that can be seen in figure 11. Only 4,44 percent of the respondent taking a furlough for using the opportunities for leave from the company. From figure 12, it is shows that the employee in PT. NK only have time around 3 until 5 hours a day for interacting with the family with the percentage of respondent 58 percent. The time for interacting with the family is only after the worktime because they have to go to work early and they only have quality time for the family in the rest of the day after working.

Figure 10: Monthly Leave of absence

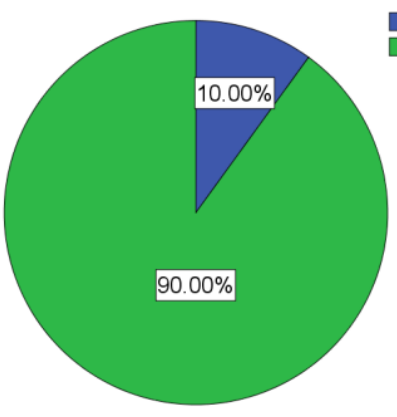

Source: Primary Data, 2019
Figure 11: Reason for having leave

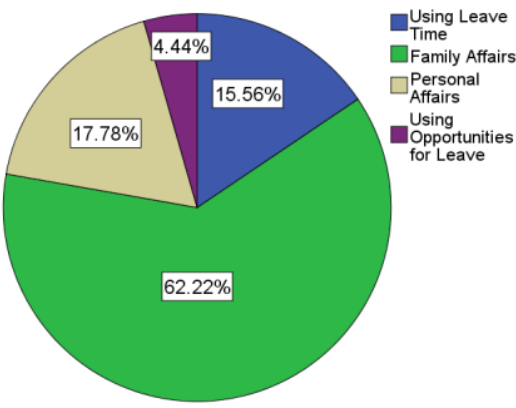

Source: Primary Data, 2019
Figure 12: Family Quality Time Intensity

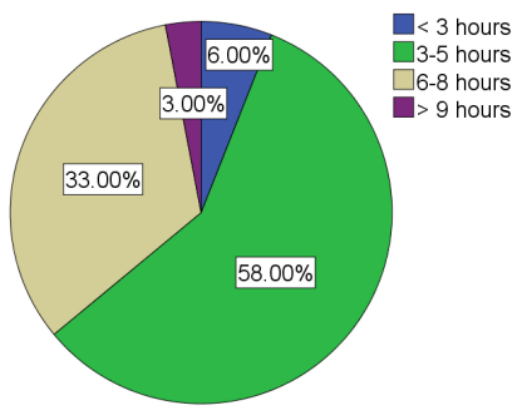

Source: Primary Data, 2019
Figure 13: Whether have an insurance

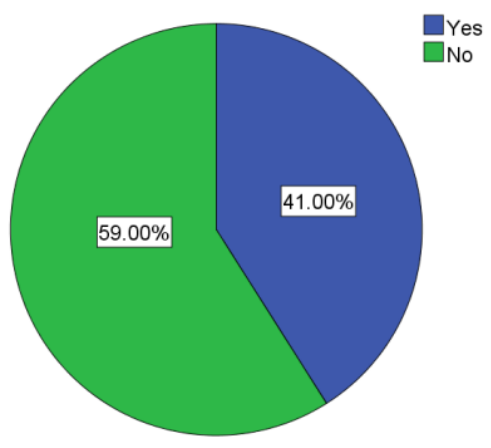

Source: Primary Data, 2019
Figure 14: Whether have an insurance

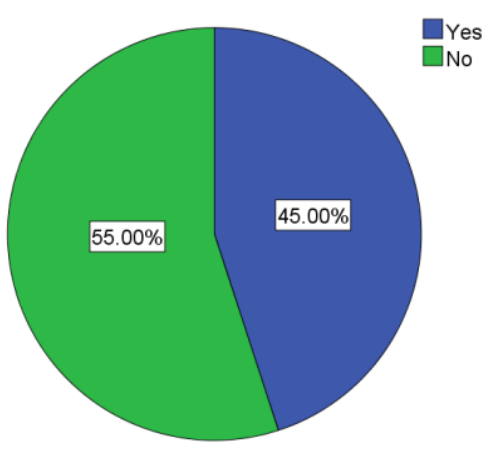

Source: Primary Data, 2019

It can be seen in figure 13, 59 percent of the respondent do not have any insurance and from 41 percent of the respondent who has insurance is most of them used for themselves. In graph 2, 55 percent of the respondent felt that the allowance gained from the company is not decrease the burden to fulfill the needs. From the 45 percent 
of the respondent who felt that the allowance can reduce the fulfillment any of respondent can save the money from the income for another needs.

Figure 15: Whether have another job

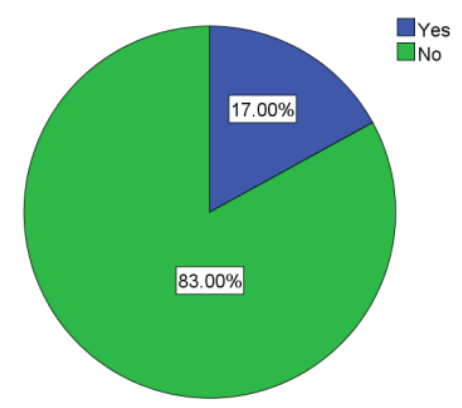

Source: Primary Data, 2019
Figure 16: Factor to make one job and another balance

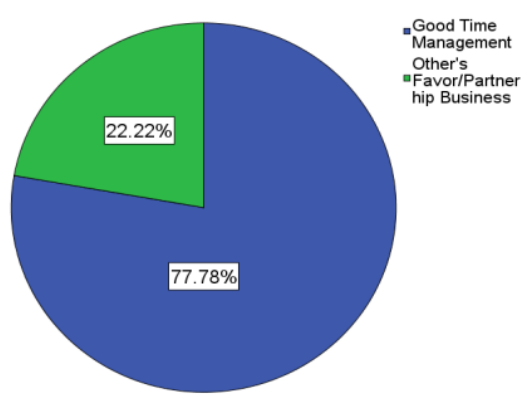

Source: Primary Data, 2019

Figure 15 shows that only 17 percent of the respondent have another job beside outside the company and 9 percent of them can make it balance between job in the company and outside company because they have a good time management by 72,73 percent. 83 percent of the percentage do not have another job outside the company because they feel that they cannot manage their time and divide the priority to make it balance between their responsible for the company and their job outside the company. the respondent feel that they do not have enough time to do other thing particularly having another job outside the company.

All of the above factors such as office distance, privately owned vehicle, family dependants, one income or double income, having someone to help or not, insurance, one job or two jobs are factors that contributes to work life balance. Work life balance therefore is a situation that both workers and employers needs to create.

\section{Discussion}

Table 4: Work Life Balance and Need Fulfillment Crosstabulation

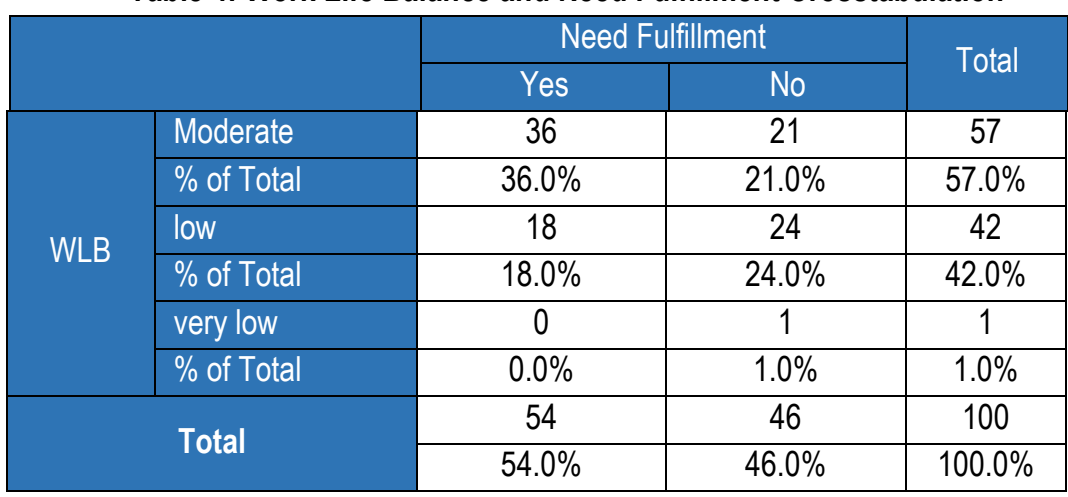

Source: Primary Data, 2019

It is shown in table 4, the employee who are in the moderate range of work-life balance has reach the need fulfilment by the income which is gained from the company. From the crosstabulation above can be seen that the company has given the employee income proportionally based on what kind of employment they have in the company. The rest by 21 percent of the respondents still feel that the income which is obtained from the company is not enough to fulfil the respondent family needs, this may be cause by the total member of the family is not balance with how much income is gotten from the company. This is also not in accordance with research conducted by Widyastuti (2012) which says that salary or income is not a factor that determines the quality of work life. 
Table 5: Work Life Balance and Housekeeper Crosstabulation

\begin{tabular}{|c|l|c|c|c|}
\hline \multicolumn{2}{|c|}{} & \multicolumn{2}{|c|}{ Housekeeper } & \multirow{2}{*}{ Total } \\
\cline { 3 - 5 } & Yes & No & \\
\hline \multirow{3}{*}{ WLB } & Moderate & 8 & 49 & 57 \\
\cline { 2 - 5 } & $\%$ of Total & $8.0 \%$ & $49.0 \%$ & $57.0 \%$ \\
\cline { 2 - 5 } & low & 4 & 38 & 42 \\
\cline { 2 - 5 } & $\%$ of Total & $4.0 \%$ & $38.0 \%$ & $42.0 \%$ \\
\cline { 2 - 5 } & very low & 1 & 0 & 1 \\
\cline { 2 - 5 } & $\%$ of Total & $1.0 \%$ & $0.0 \%$ & $1.0 \%$ \\
\hline \multirow{3}{*}{ Total } & 13 & 87 & 100 \\
\cline { 3 - 5 } & \multirow{3}{*}{ Total } & $13.0 \%$ & $87.0 \%$ & $100.0 \%$ \\
\hline
\end{tabular}

Source: Primary Data, 2019

In the table 5, almost half percentage of the total respondents by 49 percent do not have housekeeper. Meanwhile, even though they do not have a housekeeper to help their house work their work life balance still in a moderate range. This is because almost all of the employee who does not have housekeeper has a very good time management so that they can manage what they supposed to do at the company and what they should do at home. On the other side, the most respondent feel that they prefer to save their money to be used for another needs because they feel that the income sometimes is not enough to pay a housekeeper. Rest of them feel that they do not need housekeeper for their family, they can do all of the house work by them self and since few of them still living in a boarding house they do not need a housekeeper. This study relevant with Asepta (2018) that indicated personal and family matters often be a conflict toward work and professional demands. As the result many people feel that life goes beyond their control. The high-level and high-output condition is one of the consequences of the imbalance between work and life include that they couldn't manage their time and need somebody else to help at home.

Table 6: Work Life Balance and insurance Crosstabulation

\begin{tabular}{|c|l|c|c|c|}
\hline \multirow{2}{*}{} & \multicolumn{3}{|c|}{ Insurance } & \multirow{2}{*}{ Total } \\
\cline { 3 - 5 } & Moderate & Yes & No & \\
\cline { 2 - 5 } & $\%$ of Total & 17 & 40 & 57 \\
\cline { 2 - 5 } WLB & $17.0 \%$ & $40.0 \%$ & $57.0 \%$ \\
\cline { 2 - 5 } & ow of Total & 23 & 19 & 42 \\
\cline { 2 - 5 } & very low & 1 & $19.0 \%$ & $42.0 \%$ \\
\cline { 2 - 5 } & \% of Total & $1.0 \%$ & 0 & $1.0 \%$ \\
\hline \multirow{3}{*}{} & Total & 41 & 59 & 100 \\
\cline { 3 - 5 } & & $41.0 \%$ & $59.0 \%$ & $100.0 \%$ \\
\hline
\end{tabular}

Source: Primary Data, 2019

Table above shows that in the moderate work-life balance, 40 percent of the respondent still don't have any insurance even for them self or their family member. Since most of the respondent working in the company still under 5 years, they have not get the insurance yet because of the obligation given by the company that before the time decided by the company they cannot get the insurance from the company. Most of them also said that the income which is gained from the company is still not enough to be divided to pay any insurance. Study from Kerja, Hasan and As (2019) reveal that companies need to increase employee employment insurance in order to be able to improve employee performance whereby the employee performance has an influence which is positive and significant. 
Table 7: Work Life Balance and Allowance Crosstabulation

\begin{tabular}{|c|l|c|c|c|}
\hline \multicolumn{2}{|c|}{} & \multicolumn{2}{|c|}{ Allowance } & \multirow{2}{*}{ Total } \\
\cline { 2 - 5 } & Moderate & 22 & Yes & \\
\cline { 2 - 5 } & $\%$ of Total & $22.0 \%$ & $35.0 \%$ & $57.0 \%$ \\
\cline { 2 - 5 } & low & 23 & 19 & 42 \\
\cline { 2 - 5 } & $\%$ of Total & $23.0 \%$ & $19.0 \%$ & $42.0 \%$ \\
\cline { 2 - 5 } & very low & 0 & 1 & 1 \\
\cline { 2 - 5 } & $\%$ of Total & $0.0 \%$ & $1.0 \%$ & $1.0 \%$ \\
\hline \multirow{3}{*}{} & Total & 45 & 55 & 100 \\
\cline { 3 - 5 } & & $45.0 \%$ & $55.0 \%$ & $100.0 \%$ \\
\hline
\end{tabular}

Source: Primary Data, 2019

All of the respondent in PT. NK have rights to get allowance from the company. Meanwhile, 35 percent of the respondent is seen from the moderate work-life balance feel that the allowance which is gotten from the company still not enough. This means that the company still cannot notice the need of the allowance of the respondent. Furthermore, Employee allowance affects on employee performance, as more as the allowance given by the company the employee will have better performance at workplace and will not be anxious on their life within society whereby they need to feel settled for their future (Amina and Wadhan, 2016).

Table 8: Work Life Balance and Quality Time with Family Crosstabulation

\begin{tabular}{|c|c|c|c|c|c|c|}
\hline & & \multicolumn{4}{|c|}{ Quality Time with Family } & \multirow{2}{*}{ Total } \\
\hline & & $<3$ hours & $3-5$ hours & $6-8$ hours & $>9$ hours & \\
\hline \multirow{6}{*}{ WLB } & Moderate & 3 & 35 & 18 & 1 & 57 \\
\hline & $\%$ of Total & $3.0 \%$ & $35.0 \%$ & $18.0 \%$ & $1.0 \%$ & $57.0 \%$ \\
\hline & low & 3 & 22 & 15 & 2 & 42 \\
\hline & $\%$ of Total & $3.0 \%$ & $22.0 \%$ & $15.0 \%$ & $2.0 \%$ & $42.0 \%$ \\
\hline & very low & 0 & 1 & 0 & 0 & 1 \\
\hline & $\%$ of Total & $0.0 \%$ & $1.0 \%$ & $0.0 \%$ & $0.0 \%$ & $1.0 \%$ \\
\hline \multirow{2}{*}{\multicolumn{2}{|c|}{ Total }} & 6 & 58 & 33 & 3 & 100 \\
\hline & & $6.0 \%$ & $58.0 \%$ & $33.0 \%$ & $3.0 \%$ & $100.0 \%$ \\
\hline
\end{tabular}

Table 8 indicating evidence that long working hours put workers' health and relationships at risk; in particular for vulnerable groups of employees, and for those without kin help for the essential daily care of dependents and domestic responsibilities (Brien, 2011). Meanwhile, it is seen in the table above most of the respondent that is in the moderate work-life balance in the whole day the respondent only has 3 until 5 hours to have quality time with their family. Most of the respondent also feel tired after they had work and usually they only have between 3 and 5 hours for having interaction with their family and having rest to prepare work in the next day. 
Table 9: Work Life Balance and Leave of Absence Crosstabulation

\begin{tabular}{|c|l|c|c|c|}
\hline \multicolumn{2}{|c|}{} & \multicolumn{2}{|c|}{ Leave of Absence } & \multirow{2}{*}{ Total } \\
\cline { 3 - 5 } & Never & $1-3$ times & \\
\hline \multirow{3}{*}{ WLB } & Moderate & 4 & 53 & 57 \\
\cline { 2 - 5 } & $\%$ of Total & $4.0 \%$ & $53.0 \%$ & $57.0 \%$ \\
\cline { 2 - 5 } & low & 5 & 37 & 42 \\
\cline { 2 - 5 } & $\%$ of Total & $5.0 \%$ & $37.0 \%$ & $42.0 \%$ \\
\cline { 2 - 5 } & very low & 1 & 0 & 1 \\
\cline { 2 - 5 } & $\%$ of Total & $1.0 \%$ & $0.0 \%$ & $1.0 \%$ \\
\hline \multirow{3}{*}{ Total } & 10 & 90 & 100 \\
\cline { 3 - 5 } & & $10.0 \%$ & $90.0 \%$ & $100.0 \%$ \\
\hline
\end{tabular}

Source: Primary Data, 2019

In PT. NK 53 percent of the percentage is in a moderate state of work-life balance, it can be seen on how many times they can take the opportunities to take a leave of absence given by the company. For per month from the obligation given by the company all the employee only can take maximum 3 times leave of absence. Most of them having the leave of absence because they have something to do for their family and rarely because they want to take the chance to having a leave of absence. In response to these changes and conflict they generate multiple roles that individuals occupy, organization are increasingly pressured to design various kinds of practices, intended to facilitate employee's efforts to fulfill both their employment related and their personal commitments. There are number of work-life balance and flexible working arrangements. They are the clear policy statement that announces the organizations commitment for providing a flexible responsive work balance, which enables all employees to balance work and family / personal responsibilities supported by policy guideline (Ainapur et al., 2016).

Table 10: Work Life Balance and Working Family Member Crosstabulation

\begin{tabular}{|c|l|c|c|c|c|}
\hline \multirow{2}{*}{} & \multicolumn{3}{|c|}{ worked family member } & \multirow{2}{*}{ Total } \\
\cline { 3 - 6 } & Moderate & 1 person & 2 persons & 3 persons & \\
\hline \multirow{3}{*}{ WLB } & $\%$ of Total & $23.0 \%$ & 32 & 2 & 57 \\
\cline { 2 - 6 } & low & 10 & $32.0 \%$ & $2.0 \%$ & $42.0 \%$ \\
\cline { 2 - 6 } & $\%$ of Total & $10.0 \%$ & $29.0 \%$ & 3 & 42 \\
\cline { 2 - 6 } & very low & 0 & 1 & 0 & $57.0 \%$ \\
\cline { 2 - 6 } & $\%$ of Total & $0.0 \%$ & $1.0 \%$ & $0.0 \%$ & $1.0 \%$ \\
\hline \multirow{3}{*}{ Total } & 33 & 62 & 5 & 100 \\
\cline { 3 - 6 } & $33.0 \%$ & $62.0 \%$ & $5.0 \%$ & $100.0 \%$ \\
\hline
\end{tabular}

In the table above in the moderate level of work-life balance in can be seen on how many person working in the family. 32 percent of the percentage of respondent stated that in their family they are more than 1 person working. The reason why they having work is because they feel that the income which is gained from the company still not enough to fulfil their need and part of them also stated that they have been working for a long time and still want to looking for other income. Meanwhile, WLB from the employee perspective, is the maintenance of a balance between responsibilities at work and at home. Employers view the benefits or the working conditions that they provide to help employees balance the family and the work domains as work life benefits. Initially the concept of work life conflict focused on the impact of family demands on work. It now extends to the impact work has on individual stress, relationships and family well-being (Hogarth, Catheirne and Daniel, 2000).

A number of Job satisfaction factor are namely fair and decent service, placement in accordance with expertise, light work, work and equipment, equipment that supports the implementation of work, leadership and leadership and the monotonous nature of work or not (Asepta and Maruno, 2018). If employee has satisfied on their job, there will be a possibility that they will not seek another job outside the company. It is also can be seen 
in the table 11, in moderate level of work-life balance almost half of the percentage don't have another job outside the company in 47 percent of percentage. The reason is because they don't have enough time to do another thig because they have spent almost their whole time in a company. They still can not manage their time if they decide to have other job outside the company. This how the work life balance in the company still in a moderate level.

Table 11: Work Life Balance and Other Job Crosstabulation

\begin{tabular}{|c|l|c|c|c|}
\hline \multicolumn{2}{|c|}{} & \multicolumn{2}{|c|}{ Other Job } & \multirow{2}{*}{ Total } \\
\cline { 3 - 5 } & Yes & $1-3$ times & \\
\hline \multirow{3}{*}{ WLB } & Moderate & 10 & 47 & 57 \\
\cline { 2 - 5 } & $\%$ of Total & $10.0 \%$ & $47.0 \%$ & $57.0 \%$ \\
\cline { 2 - 5 } & low & 7 & 35 & 42 \\
\cline { 2 - 5 } & $\%$ of Total & $7.0 \%$ & $35.0 \%$ & $42.0 \%$ \\
\cline { 2 - 5 } & very low & 0 & 1 & 1 \\
\cline { 2 - 5 } & $\%$ of Total & $0.0 \%$ & $1.0 \%$ & $1.0 \%$ \\
\hline \multirow{2}{*}{ Total } & 17 & 83 & 100 \\
\cline { 3 - 5 } & & $17.0 \%$ & $83.0 \%$ & $100.0 \%$ \\
\hline
\end{tabular}

Source: Primary Data, 2019

By looking at the whole result of the cross tabulation. Most of the employees in PT. NK who have a moderate work life balance is seldom to take leave of absence, meanwhile using their weekend or holiday for their family. Stressful employees can cause significant loss in productivity and work performance (Goh, Watson and Sawang, 2011). Since they focus on their work during their working time their life with the family is not distracted by their work. Most of them also do not have any personal insurance and do not have another job outside the company so that they can only focus on their work in a company. Furthermore most of the employee's family get a double income because not only one person who working for the family so they can fulfill their needs in a family. Yet McGinnity, Frances and Russel (2013) also find that having a partner who is unemployed increases work-life conflict, suggesting that the negative impact of unemployment on income and wellbeing may outweigh any benefit of lower household working hours.

\section{Conclusion}

Taking into account the results of the study, it is evident that the management of PT. NK still has not reach the top of work-life balance from which is seen by the employee's perspectives. The work life balance of the employee still in a modrate level. It can be seen that most of the respondents who are in moderate work life balance still feel that the income which is obtained from the company is not enough to fulfill the respondent family needs. Because of any reason, the most respondent in a moderate level of work life balance also feel that they prefer to save their money to be used for another needs because they feel that the income is not enough to pay a housekeeper. The employee in PT. NK also feel that their work life and family life is not balance because they do not have any insurance even for them self or their family member. Since any obligation applied in the company, it become the reason why they still do not have any insurance. Most of them also said that the income which is gained from the company is still not enough to be divided to pay any insurance. All of the respondent in PT. NK have rights to get allowance from the company. Meanwhile, still any of the respondent feel that the allowance which is gotten from the company still not enough. This means that the company still cannot notice the need of the allowance of the respondent.

The work-life balance can also be measured on how much the intensity of the employee's quality time with their family, mostly the respondent who are in a moderate work life balance in PT. NK only have 3 until 5 hours to have intensity of quality time with their family. Most of the respondent feel too tired after they had work and usually they only have between 3 and 5 hours for having interaction with their family and having rest to prepare 
work in the next day. Furthermore, for per month from the obligation given by the company all the employee only can take maximum 3 times leaves of absence. Most of them having leave of absence because they have something to do for their family and rarely because they want to take the chance to having the leave of absence. Any of the respondents stated that in their family there are more than 1 person working. The reason why they having work is because they feel that the income which is gained from the company still not enough to fulfill their need and part of them also stated that they have been working for a long time and still want to looking for other income. The study also indicated that most of the respondent who are in moderate work life balance do not have other job outside the company. The reason is because they do not have enough time to do another thing because they have spent almost their whole time in a company. They still cannot manage their time if they decide to have other job outside the company.

This study supported the reseach by Fisher, Bulger and Smith (2009) that said worker's personal life in general, and not just family, is important as there may be more aspects of nonwork life aside from or in addition to family that may interfere with work. Since the dimension of PLEW is the lowest category seen by the average PT. NK supposed to give attention on the employee by noticing the dimension of PLEW. Since most of the employee is a parenting employee and their family life still interfere their work life, it is suggested that the company can give more allowance for the employee family life include day care, child care, and eldery or disable care because it can boost the interference of the employee's family life toward their work life. The employee can also give a flexible working hour so they can feel comfortable on doing their work and fulfill their responsibility as part of a family. Chang et al (2012) stated that flexible working hour had positive effects on employee productivity, job satisfaction and satisfaction with work schedule, and reduced employee absenteeism. Meanwhile, One limitation of the present study is this study only be conducted in one multinational corporation so that the result can not be generalized.

\section{References}

Afroze, R. (2019) 'Work Life Balance of White Collar Employees in a Multinational Company and a Joint Venture in Bangladesh', PEOPLE: International Journal of Social Sciences, 5(1), pp. 623-639. doi: 10.20319/pijss.2019.51.623639.

Ainapur, P. P. et al. (2016) 'Work Life Balance Policies , Practices and Its Impact on Organizational Performance', V(Vii), pp. 11-21.

Amina, R. and Wadhan, W. (2016) 'Pengaruh Tunjangan Karyawan terhadap Kinerja Karyawan di Bank Pembiayaan Rakyat Syariah (BPRS) Bakti Artha Sejahtera (BAS) Sampang', IQTISHADIA: Jurnal Ekonomi \& Perbankan Syariah, 3(1), p. 167. doi: 10.19105/iqtishadia.v3i1.1058.

Asepta, U. Y. and Maruno, S. H. P. (2018) 'Analisis Pengaruh Work-Life Balance Dan Pengembangan Karir Terhadap Kepuasan Kerja Karyawan Pt.Telkomsel, Tbk Branch Malang', Jurnal IImiah Bisnis dan Ekonomi Asia, 11(2), pp. 77-85. doi: 10.32812/jibeka.v11i2.64.

Bailyn, L. D., Robert and Kochan, T. A. (2001) 'Integrating Work Family Life: Holistic Approach', Sloan Work-Family Policy Network Advisory Board, 1, p. 66.

Brien, M. O. (2011) 'Work-Family Balance Policies Background paper prepared by'.

Chang, A. et al. (2012) 'The role of life friendly policies on employees ' work-life balance', (January). doi: 10.5172/jmo.2012.18.1.53.

Crooker, K. J., Smith, F. L. and Tabak, F. (2002) 'Creating work-life balance: A model of pluralism across life domains. Human Resource Development Review', 1(4), pp. 387-419.

Fisher, G. G. (2001) Work/personal Life Balance : A Construct Development Study. Bowling Green State University.

Fisher, G. G., Bulger, C. A. and Smith, C. S. (2009) 'Beyond Work and Family: A Measure of Work/Nonwork Interference and Enhancement', Journal of Occupational Health Psychology, 14(4), pp. 441-456. doi: 10.1037/a0016737.

Frame, P. and Hartog, M. (2003) 'From rhetoric to reality. Into the swamp of ethical practice: implementing worklife balance', Business Ethics: A European Review, 12(4), pp. 358-368. doi: 10.1111/1467-8608.00337. 
Goh, Y. W., Watson, S. and Sawang, S. (2011) 'Gender influences on the work-related stress-coping process', Journal of Individual Differences.

Greenhaus, J. H., Collins, K. M. and Shaw, J. D. (2003) 'The relation between work-family balance and quality of life', Journal of vocational behavior, 63(3), pp. 510-531.

Hogarth, T., Catheirne, B. and Daniel, G. (2000) 'Work life balance -2000: Results from the Baseline study', Department for Education and Employment, 1.

Indonesia, S. (2020) Pengangguran Terbuka Menurut Pendidikan Tertinggi yang Ditamatkan 1986 - 2019, Statistics Indonesia. Available at: https:/www.bps.go.id/statictable/2009/04/16/972/pengangguranterbuka-menurut-pendidikan-tertinggi-yang-ditamatkan-1986---2019.html.

Jaharuddin, N. S. and Zainol, L. N. (2019) 'The Impact of Work-Life Balance on Job Engagement and Turnover Intention', The South East Asian Journal of Management, 13(1). doi: 10.21002/seam.v13i1.10912.

Kanthisree, M. G. et al. (2013) 'Work Life Balance of Employees (A Study on Selected Public and Private Sector Undertakings)', Departement of Commerce and Management Studies, 1, pp. 1-24. Available at: https://shodhgangotri.inflibnet.ac.in/bitstream/123456789/1919/1/3534.pdf.

Kerja, I., Hasan, M. and As, Z. (2019) 'The Effect of Work Incentives and Work Insurance on Outsourcing Employee Performance Pt Persona Prima Utama Representative of Yogyakarta', 7(1).

Konrad, A. M. and Mangel, R. (2000) 'The impact of work-life programs on firm productivity', Strategic Management Journal, pp. 1225-1237.

Lazăr, I., Osoian, C. and Raţiu, P. (2010) 'The role of work-life balance practices in order to improve organizational performance', European Research Studies Journal, 13(1), pp. 201-213.

Leovaridis, C. and Vătămănescu, E.-M. (2015) 'Aspects Regarding Work-Life Balance of High-Skilled Employees in Some Romanian Services Sectors', Journal of Eastern Europe Research in Business \& Economics, 2015, pp. 1-15. doi: 10.5171/2015.969136.

McGinnity, Frances and Russell, H. (2013) "Work-family conflict and Economic Change" in Gallie, Duncan. (ed). Economic Crisis, Quality of Work and Social Integration: The European Experience', Oxford: Oxford University Press.

Meenakshi, M. S. P. and V, V. S. C. (2013) " The Importance of Work -Life- Balance "', IOSR Journal of Business and Management, 14(3), pp. 31-35.

Nafiudin (2015) 'Pengaruh Work Life Balance dan Kepuasan Kerja terhadap Turnover Intention Karyawan pada PT BANK AGRONIAGA TBK Cabang Bandung', Jurnal Sains Manajemen, 3(2), pp. 23-37.

Oluwasola, A. K. (2001) 'Work Life balance and employee productivity', Business Administration of the Department of Business Administration and Marketing, 1(11), p. 43.

Ouppara, N. S. and Sy, M. V. U. (2012) 'Quality of Work Life Practices in a Multinational Company in Sydney, Australia', Procedia - Social and Behavioral Sciences. Elsevier B.V., 40(032), pp. 116-121. doi: 10.1016/j.sbspro.2012.03.169.

Robbins, S. P. and Judge, T. A. (2011) 'Organizational behavior', Hoboken: NJ: Prentice Hall.

Schermerhorn, J. R., Hunt, J. G. and Osborn, R. N. (2001) Organizational Behavior, John Wiley \& Sons, Inc.

Singh, G. (2017) 'A Study Of Quality Of Work Lide In MNC', 3(2), pp. 281-282.

Sukalova, V., Ceniga, P. and Janotova, H. (2015) 'Harmonization of Work and Family Life in Company Management in Slovakia', Procedia Economics and Finance. Elsevier B.V., 26(15), pp. 152-159. doi: 10.1016/s2212-5671(15)00905-3.

Sutopo (2002) 'Penelitian Jumlah Sampel dalam Penelitian', STIE Dharmaputra Semarang, 1(3), pp. 2-6.

Unilever (2019) Improving employee health, nutrition \& well-being, Unilever's global company. Available at: https://www.unilever.com/sustainable-living/enhancing-livelihoods/fairness-in-the-workplace/improvingemployee-health-nutrition-and-well-being/index.html.

Widyastuti, U. and Purwana, D. (2012) 'Analisis Faktor-Faktor Dalam Kualitas Kehidupan Kerja (Quality Work Life) 
Volume 7, № 1 (1-18), 2020

Di Fakultas Ekonomi Universitas Negeri Jakarta', Econosains Jurnal Online Ekonomi dan Pendidikan, 10(1), pp. 71-93. doi: 10.21009/econosains.0101.07. 